\section{Ancymidol Hastens in Vitro Bud Development in Melon}

\author{
Victor Gaba $^{1}$, Chassia EIman', and Abed A. Watad ${ }^{2}$ \\ Agricultural Research Organization, Volcani Center, P.O. Box 6, Bet Dagan \\ 50250, Israel
}

Dennis J. Gray

Institute of Food and Agricultural Sciences, Central Florida Research and Education Center, University of Florida, 5523 University Avenue, Leesberg, FL 34748-8232

Additional index words. Cucumis melo, cotyledons, growth substance interaction, benzyladenine, alpha-cyclopropyl-alpha-(4-methoxy-phenyl)-5-pyrimidine methanol, antigibberellin, gibberellin, $\mathrm{GA}_{3}$

Abstract. Cotyledonary explants of melon (Cucumis melo L. cv. Galia) regenerate primordia and buds in vitro induced by benzyladenine. The anti-gibberellin ancymidol can stimulate the rate of regeneration on melon explants in the presence of benzyladenine. Concentrations of benzyladenine plus ancymidol that are individually ineffective can act synergistically to stimulate regeneration. Gibberellic acid reduces the rate of regeneration induced by benzyladenine or benzyladenine plus ancymidol. Chemical names used: $N$ (phenylmethyl)-1H-purine-6-amine (benzyladenine); alpha-cyclopropyl-alpha-(4methoxy-phenyl)-5-pyrimidine methanol (ancymidol).

There are several reports on the effect of compounds with anti-gibberellin activity on in vitro regeneration (see George, 1993). Generally, the use of anti-gibberellins leads to a stimulation of morphogenetic processes, such as production of somatic embryos in Citrus sinensis Osb. callus (Spiegel-Roy and Saad, 1986), promotion of Gladiolus spp. cormel formation (Steinitz et al., 1991; Ziv, 1989), Albizzia julibrissin Durrazz. shoot proliferation (Sankhla et al., 1993), and Philodendron hastatum $\times$ imble $\times$ wendelandii bud multiplication (Ziv and Ariel, 1991).

The initiation of regeneration is important in plant transformation. While investigating the control of the initiation of in vitro bud production by growth regulators in melon (Cucumis melo L.), we found that gibberellin status is important in regeneration. Here we report that an inhibitor of gibberellin biosynthesis also affects the kinetics of regeneration in melon.

Received for publication 28 Apr. 1996. Accepted for publication 14 June 1996. Contribution from the Agricultural Research Organization, The Volcani Center, Bet Dagan, Israel, No. 1732-E, 1995 series. This work was supported by a grant to V.G. and D.J.G. from U.S.-Israel Binational Agricultural Research and Development Fund. We thank Y. BenTal, O. Sagee, and B. Steinitz for critical comments on the manuscript. The cost of publishing this paper was defrayed in part by the payment of page charges. Under postal regulations, this paper therefore must be hereby marked advertisement solely to indicate this fact.

${ }^{1}$ Department of Virology.

${ }^{2}$ Department of Ornamental Horticulture. the cotyledons were excised from seedlings and discarded, and the remaining cotyledons a. 12 days

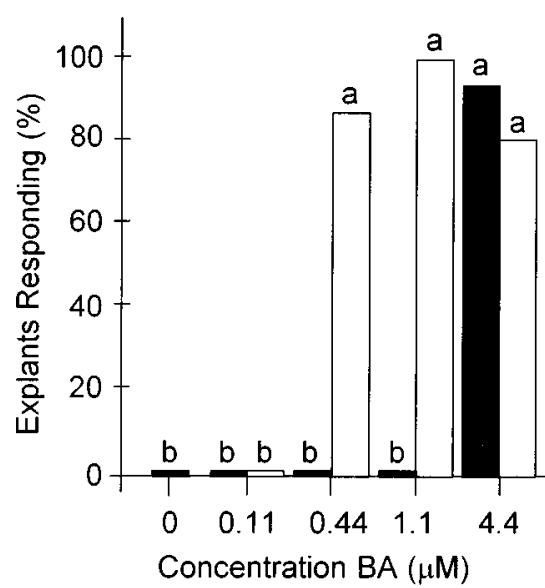
= with ancymidol. halved transversely. Only experiments using explants derived from the part proximal to the apex of the seedling are reported, as only these explants gave a consistently high regeneration response. Explants were placed in 9-cm-diameter petri dishes with the abaxial side on agarsolidified medium. The basal medium was amended with $\mathrm{N}$-(phenylmethyl)- $1 \mathrm{H}$-purine6-amine (benzyladenine) (BA), with or without $1.08 \mu \mathrm{M}$ alpha-cyclopropyl-alpha-(4methoxy-phenyl)-5-pyrimidine methanol) (ancymidol) (Elenco), or $14.5 \mu \mathrm{M} \mathrm{GA}_{3}$ (Sigma Chemicals Co., St. Louis). Explants were observed daily by a dissecting microscope and scored for the first appearance of primordia. In each treatment, 16 or 20 explants were used, four explants per petri dish. Experiments were repeated once. Results were consistent, but the timing of the response between each set of experiments varied. Means of individual pairs of results were separated by chi-squared test.

\section{Results and Discussion}

After 12 days in culture (Fig. 1a), regeneration of samples treated with ancymidol + BA was significantly better $(P \leq 0.001)$ than of samples with the intermediate concentrations $(0.44$ and $1.1 \mu \mathrm{M})$ of BA alone. At 4.4 and 0.11 $\mu_{\mathrm{M}} \mathrm{BA}$, ancymidol did not affect the response. After 28 days in culture, there was still a significant effect $(P \leq 0.03)$ of ancymidol at $0.44 \mu \mathrm{M}$ BA (Fig. 1b). Melon explants placed on growth regulator-free medium did not regenerate shoot buds, as also noted by Leshem et al. (1994). Medium containing ancymidol by itself did not promote bud regeneration (data not shown). Another compound with anti-gibberellin activity, $(2 R S, 3 R S)-\mathrm{D}(4-$ chlorophenyl)-4,4, dimethyl-2 (1H-1,2,4triazyl-1-yl pentan-3-ol) (paclobutrazol), by itself did not stimulate bud regeneration in melon (Leshem et al., 1994).

The morphogenetic effect of ancymidol was observed at an early developmental stage (appearance of the first primordia) (Fig. 1a). b. 28 days

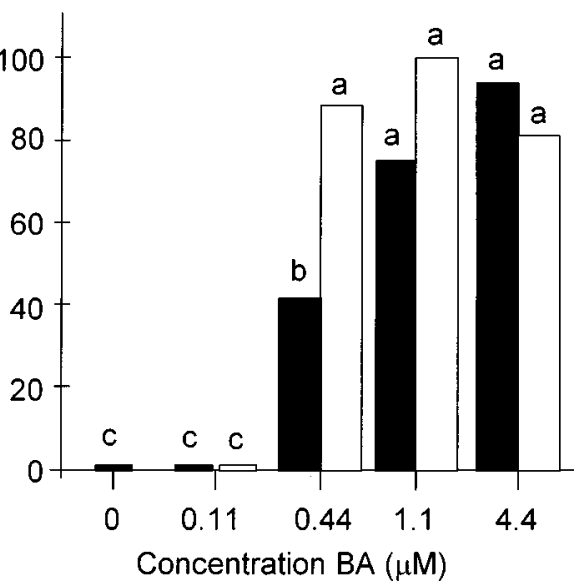

Fig. 1. Effect of benzyladenine (BA) on regeneration of melon explants in the presence of ancymidol Percentage of explants regenerating with and without $1.08 \mu \mathrm{M}$ ancymidol were scored after 12 days (a: primordia) and 28 days (b: buds). Individual pairs of results were separated by chi-squared test. Mean separation within pairs in a at $P \leq 0.01$, and in $\mathbf{b}$ at $P \leq 0.05$. Solid bars $=$ without ancymidol; hollow bars 
Propagation \& Tissue Culture

Therefore, inhibitors of gibberellin biosynthesis affect not only the final growth response (Sankhla et al., 1993; Spiegel-Roy and Saad, 1986; Steinitz et al., 1991; Ziv, 1989), but can also affect the rate of developmental processes. Also, the interaction between BA and the inhibitor of gibberellin biosynthesis is only observable at nonsaturating levels of BA (i.e., $1.1 \mu \mathrm{M}$ or less). Additionally, after 12 days in culture there is a synergism at a BA concentration of $0.44 \mu \mathrm{M}$ between the cytokinin and the anti-gibberellin (Fig. 1a): i.e., the compounds separately cannot elicit any response $(0 \%)$, but together the response is large ( $88 \%)$. BA activity is only evident after 12 days at the highest concentration $(4.4 \mu \mathrm{M})$, and effects of the lower concentrations are only noticeable after 28 days (Fig. 1). However, ancymidol action started more rapidly, and to about the same extent at $0.44 \mu \mathrm{MBA}$ at 12 days to 28 days (Fig. 1).

Ancymidol functions by specifically blocking the pathway of gibberellin biosynthesis (Graebe, 1987), thereby reducing the level of endogenous gibberellins. Theoretically, the reduction of endogenous gibberellin permits BA to stimulate primordia and bud development. This theory is bolstered by the fact that addition of gibberellins to regeneration media often reduces morphogenesis (see George, 1993). We also find this with in vitro development of melon. In another series of experiments, in the presence of $4.4 \mu \mathrm{M} \mathrm{BA}, 95 \%$ of explants began regeneration after 13 days in

Table 1. Regeneration of primordia on melon cotyledons under the influence of benzyladenine (BA), ancymidol (ANC), and gibberellic acid $\left(\mathrm{GA}_{3}\right)$.

\begin{tabular}{llcc}
\hline \hline $\begin{array}{l}\text { Days of } \\
\text { treatment }\end{array}$ & \multicolumn{3}{c}{ Explants with primordia (\%) } \\
\cline { 2 - 4 } $\mathrm{BA}^{\mathrm{z}}$ & $\mathrm{BA}+\mathrm{ANC}$ & $\mathrm{BA}+\mathrm{ANC}+\mathrm{GA}_{3}$ \\
\hline 13 & $0 \mathrm{a}^{\mathrm{y}}$ & $60 \mathrm{~b}$ & $5 \mathrm{a}$ \\
17 & $0 \mathrm{a}$ & $80 \mathrm{c}$ & $40 \mathrm{~b}$ \\
\hline
\end{tabular}

${ }^{2}$ Explants were incubated in the presence of BA $(0.44 \mu \mathrm{M})$, or with the addition of ancymidol $(1.08 \mu \mathrm{M})$, or ancymidol and $\mathrm{GA}_{3}(14.5 \mu \mathrm{M})$, and the appearance of primordia was scored.

${ }^{y}$ Mean separation at $P \leq 0.01$ by paired chi-squared test.

culture, compared to $40 \%$ of explants incubated with $4.4 \mu \mathrm{M} \mathrm{BA}+14.5 \mu \mathrm{M} \mathrm{GA}_{3}$ (statistically significant at $P \leq 0.01$ ). Additionally, at a concentration of BA at which the ancymidol has a strong effect we find that the response to ancymidol is reversed by the simultaneous application of $\mathrm{GA}_{3}$ and that the effect of $\mathrm{GA}_{3}$ is reduced with time (Table 1).

In conclusion, these results demonstrate that ancymidol promotes regeneration in melon at low levels of exogenous BA, demonstrating a synergistic effect between an inhibitor of gibberellin synthesis and a cytokinin.

\section{Literature Cited}

George, E.F. 1993. Plant propagation by tissue culture. Part 1: The technology. 2nd ed. Exegetics, Edington, England.

Graebe, J.E. 1987. Gibberellin biosynthesis and control. Annu. Rev. Plant Physiol. 38:419-465.

Leshem, B., R. Ronen, and S. Lurie. 1994. Thidiazuron and paclobutrazol appear to mimic cytokinin and auxin influences on organ regeneration and protein profiles in cultured melon cotyledons. J. Plant Physiol. 143:344-388.

Murashige T. and F. Skoog. 1962. A revised medium for rapid growth and bio-assays with tobacco tissue cultures. Physiol. Plant. 15:473479.

Sankhla, D., T.D. Davis, and N. Sankhla. 1993. Effect of gibberellin biosynthesis inhibitors on shoot regeneration from hypocotyl explants of Albizzia julibrissin. Plant Cell Rpt. 13:115-118.

Spiegel-Roy, P. and S. Saad. 1986. Effect of carbohydrates and inhibitors of $\mathrm{GA}_{3}$ biosynthesis on embryonic potential of salt tolerant and nontolerant callus lines of orange (Citrus sinensis Osbeck). Plant Sci. 47:215-220.

Steinitz, B., A. Cohen, Z. Goldberg, and M. Kochba. 1991. Precocious gladiolus corm formation in liquid shake flasks. Plant Cell, Tissue \& Organ Culture 26:63-70.

Ziv, M. 1989. Enhanced shoot and cormlet proliferation in liquid cultured gladiolus buds by growth retardents. Plant Cell, Tissue \& Organ Culture 17:101-110.

Ziv, M. and T. Ariel. 1991. Bud proliferation and plant regeneration in liquid-cultured Philodendron treated with ancymidol and paclobutrazol. J. Plant Growth Regulation 10:53-57. 